LM-01K03

May 8, 200

\title{
Measurement of the Nickel/Nickel Oxide Phase Transition in High Temperature Hydrogenated Water Using the Contact Electric Resistance (CER) Technique
}

Steven A. Attanasio, David S. Morton, Mark A. Ando,

Nicholas F. Panayotou, Charles D. Thompson

This report was prepared as an account of work sponsored by the United States Government. Neither the United States, nor the United States Department of Energy, nor any of their employees, nor any of their contractors, subcontractors, or their employees, makes any warranty, express or implied, or assumes any legal liability or responsibility for the accuracy, completeness or usefulness of any information, apparatus, product or process disclosed, or represents that its use would not infringe privately owned rights. 


\title{
Measurement of the Nickel/Nickel Oxide Phase Transition in High Temperature Hydrogenated Water Using the Contact Electric Resistance (CER) Technique
}

\author{
Steven A. Attanasio, David S. Morton, Mark A. Ando, Nicholas F. Panayotou and Charles D. Thompson \\ Lockheed Martin Corporation \\ P.O. Box 1072 - Schenectady, NY 12301
}

\begin{abstract}
Prior studies of Alloy 600 and Alloy X-750 have shown the existence of a maximum in stress comosion cracking $(\mathrm{SCC})$ susceptibility in high temperature water $\left(e . g\right.$., at $\left.360^{\circ} \mathrm{C}\right)$, when testing is conducted over a range of dissolved (i.e., aqueous) hydrogen $\left(\mathrm{H}_{2}\right)$ concentrations. It has also been shown that this maximum in SCC susceptibility tends to occur in proximity to the nickel/nickel oxide $(\mathrm{Ni} / \mathrm{NiO})$ phase transition, suggesting that oxide phase stability may affect primary water SCC (PWSCC) resistance. Previous studies have estimated the Ni/NiO transition using thermodynamic calculations based on free energies of formation for $\mathrm{NiO}$ and $\mathrm{H}_{2} \mathrm{O}$. The present study reports experimental measurements of the $\mathrm{Ni} / \mathrm{NiO}$ transition performed using a contact electric resistance (CER) instrument. The CER is capable of measuring the surface resistance of a metal to determine whether it is oxide-covered or oxide-free at a given condition. The transition aqueous hydrogen $\left(\mathrm{H}_{2}\right)$ concentration corresponding to the $\mathrm{Ni} / \mathrm{NiO}$ equilibrium was measured at $288,316,338$ and $360^{\circ} \mathrm{C}$ using high purity $\mathrm{Ni}$ specimens. The results showed an appreciable deviation (i.e., 7 to $58 \mathrm{scc} \mathrm{H}_{2} / \mathrm{kg} \mathrm{H}_{2} \mathrm{O}$ ) between the measured $\mathrm{Ni} / \mathrm{NiO}$ transition and the theoretical $\mathrm{Ni} / \mathrm{NiO}$ transition previously calculated using free energy data from the Journal of Solution Chemistry. The CERmeasured position of the $\mathrm{Ni} / \mathrm{NiO}$ transition is in good agreement with the maxima in PWSCC susceptibility at 338 and $360^{\circ} \mathrm{C}$. The measured $\mathrm{Ni} / \mathrm{NiO}$ transition provides a reasonable basis for estimating the aqueous $\mathrm{H}_{2}$ level at which the maximum in SCC susceptibility is likely to be observed at temperatures lower than 338 to $360^{\circ} \mathrm{C}$, at which SCC tests are time-consuming to perform. Limited SCC data are presented which are consistent with the observation that SCC susceptibility is maximized near the $\mathrm{Ni} / \mathrm{NiO}$ transition at $288^{\circ} \mathrm{C}$.
\end{abstract}

\section{Introduction}

Extensive testing conducted at various aqueous $\mathrm{H}_{2}$ levels and temperatures (e.g., 338, 360 and $399^{\circ} \mathrm{C}$ ) has shown that a maximum in PWSCC susceptibility exists for nickel-based alloys in proximity to the $\mathrm{Ni} / \mathrm{NiO}$ equilibrium. ${ }^{1-5}$ The theory that the stability of NiO influences PWSCC is supported by analytical electron microscopy (AEM) studies in which the crack tip oxide often exhibits a $\mathrm{NiO}$ crystal structure (i.e., $\mathrm{Ni}(\mathrm{Cr}, \mathrm{Fe}) \mathrm{O}$ ) as opposed to the spinel structure oxides (i.e., $\mathrm{Ni}_{x} \mathrm{Fe}_{1-x} \mathrm{Cr}_{y} \mathrm{Fe}_{2-y} \mathrm{O}_{4}$ ) typically found on the external metal surface. ${ }^{6}$ Spinel structure oxides have also been observed at the crack tip in some cases. ${ }^{7}$

Thermodynamic properties have been used in prior work to predict the stability domains of $\mathrm{Ni}$ and $\mathrm{NiO}$ at different aqueous $\mathrm{H}_{2}$ levels. ${ }^{1,3,8}$ Changing the aqueous $\mathrm{H}_{2}$ level can stabilize or destabilize $\mathrm{NiO}$, consistent with LeChatelier's Principle. This effect is due to the reaction between $\mathrm{NiO}$ and $\mathrm{H}_{2}$ (i.e., $\mathrm{NiO}+\mathrm{H}_{2}=\mathrm{Ni}+\mathrm{H}_{2} \mathrm{O}$ ). Calculations indicate that the amount of $\mathrm{H}_{2}$ required to reduce $\mathrm{NiO}$ to $\mathrm{Ni}$ increases as the temperature is increased. Since the accuracy of theoretical predictions is limited by uncertainties in thermodynamic properties such as free energies of formation, there is a benefit to experimentally evaluating film stability regimes using an instrument such as the CER.

\section{Experimental Procedure}

The CER method was first utilized by Marichev ${ }^{9}$, and has been used extensively by Saario and co-workers ${ }^{9.11}$ to analyze surface resistance in several metal-environment systems. The CER setup used in the present study employed 2 cylindrical specimens (diameter $-2 \mathrm{~mm}$ ) aligned end-to-end (Figure 1), in an autoclave capable of operating up to $360^{\circ} \mathrm{C}$. Nickel $(99.5 \mathrm{wt} \%)$ was used as a test specimen and Iridium (Ir) was used as an oxide-free inert specimen. The specimens were held apart with a user-adjustable gap (approximately $2.5 \mu \mathrm{m}$ ) and were attached to a mechanism that periodically pressed the specimens into contact and then retracted them to restore the gap. The specimens were contacted every 10 minutes, for a duration of 5 seconds. A shunt resistor $\left(R_{2}\right)$ was placed in parallel with the specimens (Figure 1), and an ohmmeter was used to perform two resistance measurements: (i) specimens out-of-contact, and (ii) specimens in-contact. The difference in measured resistance between the two 


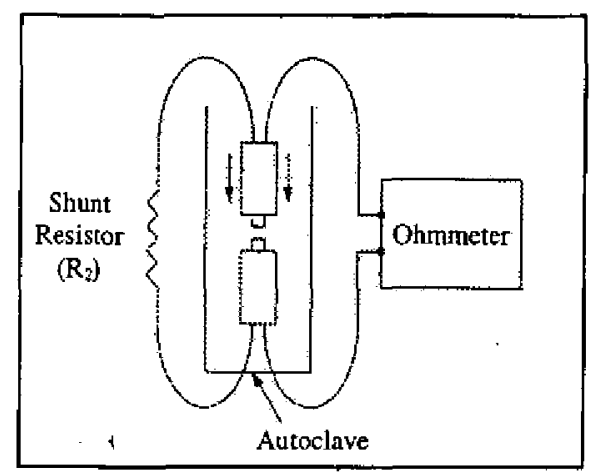

Figure 1. Schematic of the CER setup. positions is $\Delta R$ ( $\left.\Delta R=\mid R_{\text {ow }}-R_{\text {in }}\right)$. Using parallel resistor laws, it can be shown ${ }^{11}$ that the resistance of the specimen $\left(R_{S}\right)$ is:

$$
R_{S}=\frac{R_{2}^{2}}{\Delta R}-R_{2}
$$

Tests were conducted by varying the $\mathrm{H}_{2}$ level and measuring $R_{S} v s$. time. The CER is particularly effective in distinguishing between film-free and oxide-filmed states, due to the 2-6 order of magnitude difference ${ }^{10}$ in resistance between these conditions (it was found in the present work that a $10 \Omega$ shunt resistor provides acceptable data at both high and low resistance values). Note that the present study did not aim to measure absolute film resistance, but rather focused on distinguishing the film-free and oxide-filmed states. This distinction is important, since a concern relative to resistance values measured using the CER is that the actual contact area is unknown due to surface roughness. Thus, absolute resistance values are subject to an error with a magnitude that is difficult to estimate; this error, however, does not affect the utility of the present measurements. Although the performance of the CER system was excellent in most respects, one persistent problem was that as a test progressed, the specimens slowly drifted apart for a reason which is unknown. This issue is relevant because it sometimes led to a slight apparent increase in resistance during a test. This artifact arises when the specimen gap increases and effective specimen contact is diminished. The decreasing contact area is registered as a minor apparent increase in resistance. Fortunately, this specimen drift was readily distinguishable from film growth, since the software permits manual readjustment of the 'home' position of the specimens to the initial gap dimension. Any slight increase in resistance which had occurted due to specimen drift was discernible upon readjusting the 'home' position since a clear decrease in resistance, which appeared as an offset in the resistance versus time data, was observed. The reason for the home position drift is unknown at present, though creep of the zirconium spring is a possible cause.

Testing was conducted in deaerated water buffered to a high temperature $\mathrm{pH}$ of $\sim 7$. The desired $\mathrm{H}_{2}$ concentrations were obtained by varying the feed tank $\mathrm{H}_{2}$ overpressure according to Henry's law. The room temperature $\mathrm{H}_{2}$ calculations were conducted using a Henry's law coefficient ${ }^{12}$ of $0.85 \mathrm{psia} /(\mathrm{scc} / \mathrm{kg})$, the solubility of hydrogen in water at $25^{\circ} \mathrm{C}$ (note that an air conditioner was utilized to prevent appreciable changes in ambient temperature in the laboratory). Mixed gas of 4 or $14.7 \%$ hydrogen with the balance being argon was used to obtain coolant hydrogen levels less than $20 \mathrm{scc} / \mathrm{kg} \mathrm{H}_{2}$. Electrochemical corrosion potentials (ECPs) were measured vs. a platinum (Pt) electrode as well as an iron/iron oxide $\left(\mathrm{Fe} / \mathrm{Fe}_{3} \mathrm{O}_{4}\right)$ electrode. Niedrach ${ }^{13}$ has shown that if the $\mathrm{pH}$ of the environment is essentially constant and reasonably well known (as is the case for the buffered water used in the present study), the $\mathrm{Fe} / \mathrm{Fe}_{3} \mathrm{O}_{4}$ electrode exhibits a unique (and calculable) potential on the standard hydrogen electrode (SHE) scale.

\section{Results and Discussion}

\section{Resistance versus time data}

The ability of the CER to detect the nucleation and growth of an oxide film is shown in Figure 2. The initial $\mathrm{H}_{2}$ level in this test was $60 \mathrm{scc} / \mathrm{kg}$, which was predicted by thermodynamic calculations ${ }^{3}$ to be in the $\mathrm{Ni}$ metal regime at $316^{\circ} \mathrm{C}$. Indeed, a very low resistance $(<0.002 \Omega$ ) was observed, consistent with values measured by Ehrnsten and Saario ${ }^{10}$ for $\mathrm{Ni}$ at 30 $\mathrm{scc} / \mathrm{kg}$ at $320^{\circ} \mathrm{C}$. From this point, the aqueous $\mathrm{H}_{2}$ level was decreased incrementally, to determine the $\mathrm{H}_{2}$ level at which an appreciable increase in resistance (corresponding to oxide formation) occurred. Very low resistances were measured at $60,20,15$, and $10 \mathrm{scc} / \mathrm{kg}$ as shown in Figure 2. Although a very minor increase in resistance can be discerned at

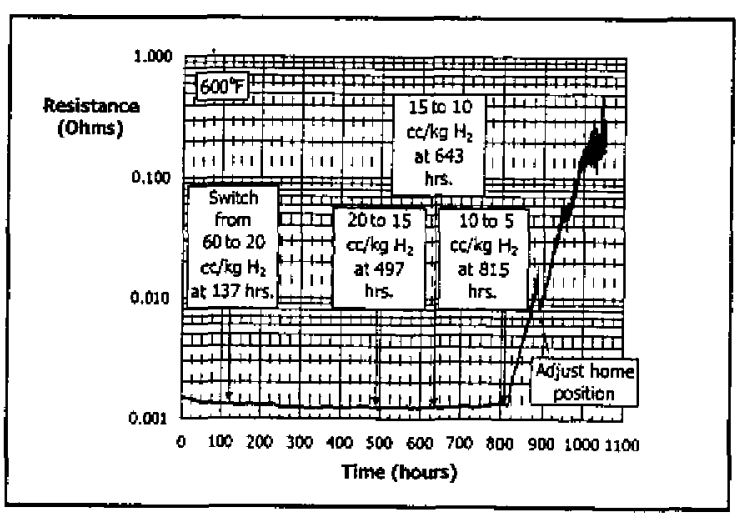

Figure 2. Resistance vs. time data at $316^{\circ} \mathrm{C}$. 
$10 \mathrm{scc} / \mathrm{kg} \mathrm{H}$, it is strongly suspected that this increase is due to the drifting apart of the specimens, based on the fact that two subsequent tests at $316^{\circ} \mathrm{C}$ confirmed that no film formation occurred at $10 \mathrm{scc} / \mathrm{kg} \mathrm{H}_{2}$. (In addition, it has been observed that during film growth, the rate of increase in resistance with time is far greater than that corresponding to the minor increase at $10 \mathrm{scc} / \mathrm{kg} \mathrm{H}_{2}$ in Figure 2.) Reducing the $\mathrm{H}_{2}$ level from 10 to $5 \mathrm{scc} / \mathrm{kg}$ led to an increase in resistance of more than two orders of magnitude, initiating within $\sim 5$ hours after the reduction in $\mathrm{H}_{2}$ level. The observation of a dramatic increase in resistance upon transitioning from a film-free to a film-covered state is consistent with prior work by Ehrnsten and Saario ${ }^{10}$. Although the maximum resistance values attained in Figure $2(\sim 0.1$ to $0.2 \Omega)$ are somewhat lower than the values of $\sim 5$ to $20 \Omega$ previously observed ${ }^{10}$ for the film-covered condition, the resistance values in Figure 2

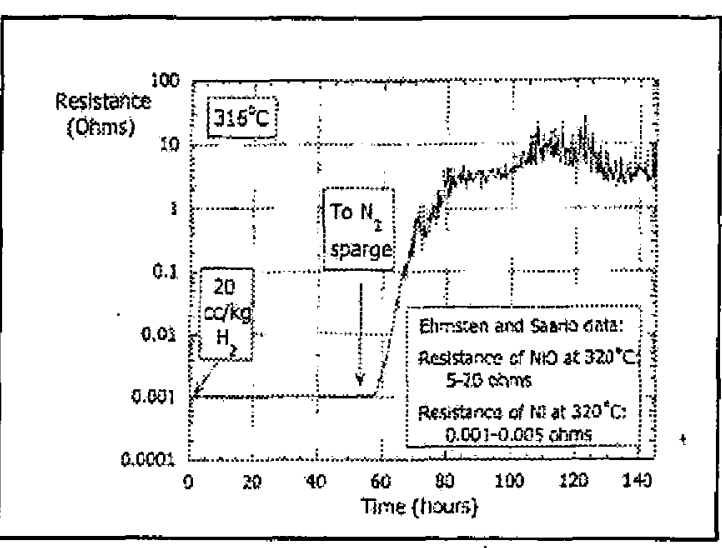

Figure 3. Resistance vs. time data at $316^{\circ} \mathrm{C}$ still appeared to be increasing when the test was terminated prematurely due to system problems. A subsequent test was conducted at $316^{\circ} \mathrm{C}$, as shown in Figure 3, in which the film was permitted to grow to an essentially steady-state resistance of -3 to $10 \Omega$. This test was conducted by sparging with nitrogen $\left(\mathrm{N}_{2}\right)$ rather than $\mathrm{H}_{2}$, which is the same condition at which Ehrnsten and Saario ${ }^{10}$ measured -5 to $20 \Omega$.

Five separate tests conducted at $316^{\circ} \mathrm{C}$ demonstrate that a dramatic increase in resistance, attributed to the formation of an oxide film, was reproducibly obtained at the $5 \mathrm{scc} / \mathrm{kg} \mathrm{H}$ condition. Thus, it can be stated with confidence that this condition resides in the $\mathrm{NiO}$ stability regime. However, it is more difficult to assess the situation at 10,15 , and $20 \mathrm{scc} / \mathrm{kg}$ $\mathrm{H}_{2}$. Although no apparent film formation occurred at these conditions in the test shown in Figure 2, it is not clear whether an oxide film would have formed under these conditions if the test had been conducted for a longer duration at each condition. For this reason, two criteria were applied before rendering a judgement that a particular $\mathrm{H}_{2}$ /temperature condition resides in the $\mathrm{Ni}$ stability regime: (i) when starting with a film-free surface, a very low resistance ( $<0.002 \Omega$ ) must be measured at the condition of interest, implying that film formation had not occurred, and (ii) an existing or a growing oxide film must exhibit reduction at the condition of interest. This concept is illustrated in Figure 4 (a), which shows a test conducted at $316^{\circ} \mathrm{C}$. A low resistance typical of a film-free state is obtained at $40 \mathrm{scc} / \mathrm{kg} \mathrm{H}$. The hydrogen level was subsequently decreased to $5 \mathrm{scc} / \mathrm{kg}$ at 119 hours. This decrease is registered by the electrochemical potential data in Figure $4(\mathrm{~b})$, where the corrosion potential $\left(\mathrm{E}_{\text {carr }}\right)$ for both $\mathrm{Pt}$ and $\mathrm{Ni}$ increases with respect to the $\mathrm{Fe} / \mathrm{Fe}_{3} \mathrm{O}_{4}$ electrode, consistent with expectations for a reduction in $\mathrm{H}_{2}$ level. At the $5 \mathrm{scc} / \mathrm{kg} \mathrm{H}_{2}$ condition, a very clear increase in

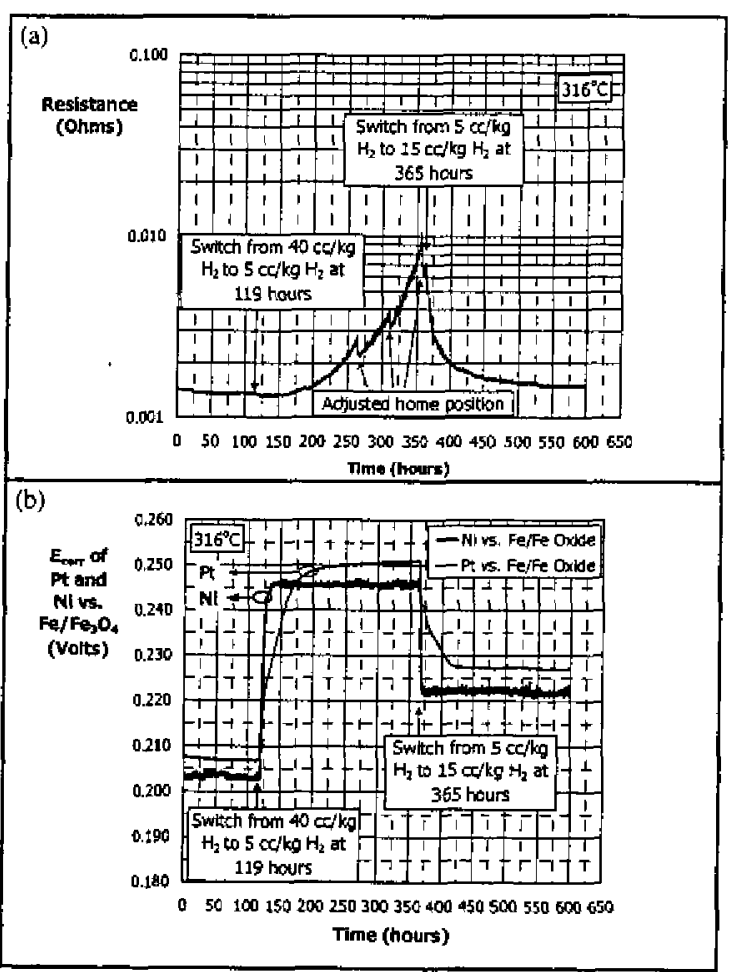

Figure 4. Resistance (a) and ECP (b) data at $316^{\circ} \mathrm{C}$. resistance ( $\sim 1$ order of magnitude) is obtained, implying that oxide film growth is occurring. At 365 hours, shortly after an adjustment in the home position, the hydrogen level was increased to $15 \mathrm{scc} / \mathrm{kg}$. This increase in aqueous $\mathrm{H}_{2}$ level is registered by a decrease in $\mathrm{E}_{\text {corr }}$ for both $\mathrm{Pt}$ and $\mathrm{Ni}$ as shown in Figure 4 (b). An immediate and very clear decrease in resistance is obtained. These data imply that at $316^{\circ} \mathrm{C}, 15 \mathrm{scc} / \mathrm{kg} \mathrm{H}_{2}$ resides in the Ni regime.

Resistance data obtained in this study are shown in Table 1 . As stated previously, film formation was observed at 5 $\mathrm{scc} / \mathrm{kg} \mathrm{H}_{2}$ in five separate tests at $316^{\circ} \mathrm{C}$ (i.e., test \# 4,6,7,8 and 9), implying that this condition corresponds to the 
$\mathrm{NiO}$ regime. However, film formation was not observed at 10 scc/ $/ \mathrm{kg}$ in three separate tests at $316^{\circ} \mathrm{C}$, and partial reduction of a growing film was also observed at $10 \mathrm{scc} / \mathrm{kg}$ at $316^{\circ} \mathrm{C}$, as shown in Figure 5, implying that this condition corresponds to the $\mathrm{Ni}$ regime. It should be noted that for certain cases (as indicated in Table 1 and illustrated by Figure 5 (a)), a partial but not complete reduction of an existing or growing film was observed. In this case, a judgement was made that if a clear and immediate decrease in resistance was evident upon transitioning to a given $\mathrm{H}_{2}$ level and if no film formation was observed at the same $\mathrm{H}_{2}$ level, that this condition was judged to be in the $\mathrm{Ni}$ regime. One reassuring aspect of this judgement is that when film formation was noted, the increase in resistance was typically evident within several hours. In fact, the data in Figure 4 (a), in which - 50 to 100 hours elapsed between the change in aqueous $\mathrm{H}_{2}$ level and the initial increase in resistance, represents by far the slowest film formation events observed in this study. In nearly every other test, less than 10 hours was needed between the change in aqueous $\mathrm{H}_{2}$ level and the observation of the initial increase in resistance (see Figures 2, 3,5 and 6). Thus, although the reduction of the growing oxide was not complete at $10 \mathrm{scc} / \mathrm{kg}$ $\mathrm{H}_{2}$ at $316^{\circ} \mathrm{C}$, it is judged that this condition corresponds to the Ni regime since no film formation was evident for three separate tests conducted for 92,101 and 172 hours at this condition (Table 1). Thus, at $316^{\circ} \mathrm{C}$, the $\mathrm{Ni} / \mathrm{NiO}$ transition is estimated as $7.5 \pm 2.5 \mathrm{scc} / \mathrm{kg} \mathrm{H}_{2}$.

Data at $338^{\circ} \mathrm{C}$ are shown in Figure 6 (a). Very low resistance values indicative of a film-free condition are evident at 40,19 and $15 \mathrm{scc} / \mathrm{kg} \mathrm{H}$. A significant increase in resistance, indicative of film formation, was noted at $10 \mathrm{scc} / \mathrm{kg} \mathrm{H}_{2}$, with the increase initially occurring about 7 hours after the $\mathrm{H}_{2}$ level was reduced from 15 to $10 \mathrm{scc} / \mathrm{kg}$. At 283 hours, the $\mathrm{H}_{2}$ level was increased to $15 \mathrm{scc} / \mathrm{kg}$; note again that this increase was registered by the $E_{\mathrm{cor}}$ data as shown in Figure 6 (b). An immediate and very clear decrease in resistance was obtained. A subsequent increase in $\mathrm{H}_{2}$ level to $19 \mathrm{scc} / \mathrm{kg}$ appeared to cause little if any additional film reduction. These data indicate that at $338^{\circ} \mathrm{C}, 10 \mathrm{scc} / \mathrm{kg} \mathrm{H}$ resides in the NiO regime while 15,19 and $40 \mathrm{scc} / \mathrm{kg}$ reside in the $\mathrm{Ni}$ regime. It is noted in Figure 6 (a) that the final resistance value after film formation and reduction was slightly greater than the initial resistance value. However, the final resistance value was extremely low $(<0.002 \Omega$ ) and this condition is thus judged to represent complete reduction. This phenomenon was commonly observed, though the reason is not known. It can be speculated that roughening of the surface by corrosion during oxide formation may have led to a decrease in the contact area and a subsequent apparent increase in resistance after the oxide formation and reduction process, though no data are available to confirm this hypothesis.

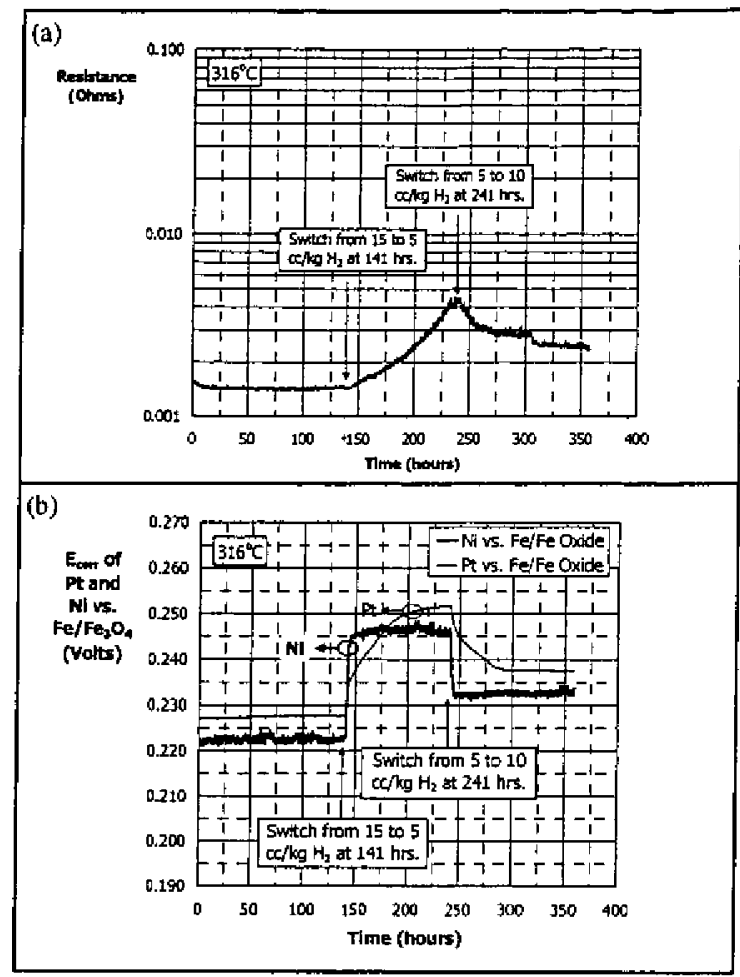

Figure 5. Resistance $(a)$ and $E C P(b)$ data at $316^{\circ} \mathrm{C}$.

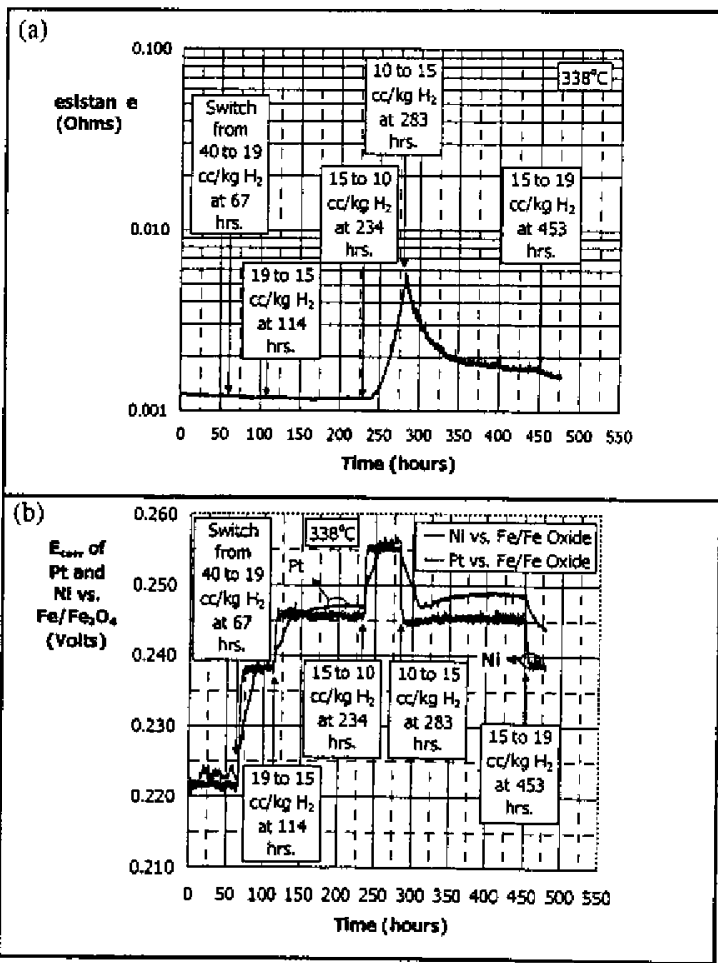

Figure 6. Resistance (a) and ECP (b) data at $338^{\circ} \mathrm{C}$. 
Table 1. Film formation and reduction data measured via CER testing.

\begin{tabular}{|c|c|c|c|c|c|c|c|c|c|c|}
\hline $\begin{array}{c}\text { Test } \\
\#\end{array}$ & $\begin{array}{c}\mathrm{T} \\
\left({ }^{\circ} \mathrm{C}\right)\end{array}$ & $\begin{array}{c}\text { Test } \\
\text { Phase }\end{array}$ & $\begin{array}{c}\text { Dissolved } \\
\mathrm{H}_{2} \text { level } \\
\text { (scc/kg) }\end{array}$ & $\begin{array}{c}\mathbf{E C P}_{\mathrm{Ni}} \boldsymbol{v s .} \\
\mathrm{Fe} / \mathrm{Fe}_{3} \mathrm{O}_{4} \\
(\mathrm{~V})\end{array}$ & $\underset{\left(\mathbf{V}_{\mathrm{SHE}}\right)^{[1]}}{\mathbf{E C P}}$ & $\begin{array}{c}\mathrm{ECP}_{\mathrm{pt}} v s . \\
\mathrm{Fe}^{\prime} \mathrm{Fe}_{3} \mathrm{O}_{4} \\
(\mathrm{~V})\end{array}$ & $\underset{\left(\mathbf{V}_{\text {SHE }}\right)}{\mathbf{E C P}_{\mathbf{P t}}{ }^{[1]}}$ & $\begin{array}{c}\text { Calculated } \\
\mathbf{H}_{\mathbf{2}} \text { fugacity } \\
\text { (atm) }^{[3 !}\end{array}$ & $\begin{array}{c}\text { Time } \\
\text { interval } \\
\text { (hours) }\end{array}$ & Result \\
\hline \multirow{6}{*}{1} & \multirow{6}{*}{288} & 1.1 & 19 & 0.196 & -0.720 & $\mathrm{~N} / \mathrm{A}^{[2]}$ & $\mathrm{N} / \mathrm{A}^{[3]}$ & 0.20 & 0 to 19 & No film formation \\
\hline & & 1.2 & 10 & 0.211 & -0.705 & 0.215 & .0 .701 & 0.11 & 19 to 92 & No film formation \\
\hline & & 1.3 & 5 & 0.227 & -0.689 & $N / A^{[2]}$ & $\mathrm{N} / \mathrm{A}^{[2]}$ & 0.05 & 92 to 163 & No film formation \\
\hline & & 1.4 & 3 & 0.234 & -0.682 & 0.236 & -0.680 & 0.03 & 163 to 433 & Film formation \\
\hline & & 1.5 & 5 & 0.223 & .0 .693 & 0.224 & -0.692 & 0.05 & 433 to 623 & Findediction \\
\hline & & 1.6 & 10 & 0.209 & -0.707 & 0.210 & -0.706 & 0.11 & 623 to 810 & Film reduction \\
\hline \multirow{3}{*}{2} & \multirow{3}{*}{288} & 2.1 & 10 & 0.208 & -0.708 & 0.208 & $-0 . \overline{708}$ & 0.11 & 0 to 144 & No film formation \\
\hline & & 2.2 & $\mathrm{~N}_{2}$ sparge & $\mathrm{N} / \mathrm{A}^{(2)}$ & $N / A^{(2)}$ & $N / A^{[?]}$ & $N / A^{(2)}$ & $\mathrm{N} / \mathrm{A}$ & 144 to 164 & Film formation \\
\hline & & 2.3 & 5 & 0.220 & $-0 . \overline{696}$ & 0.219 & -0.697 & 0.05 & 164 to 335 & Filu reduction \\
\hline \multirow{4}{*}{3} & \multirow{4}{*}{316} & 3.1 & 60 & 0.193 & -0.756 & 0.197 & -0.752 & 0.43 & 0 to 116 & No film formation \\
\hline & & 3.2 & 40 & 0.203 & -0.746 & 0.206 & -0.743 & 0.29 & 116 to 194 & No film formation \\
\hline & & 3.3 & 30 & 0.211 & -0.738 & 0.212 & -0.737 & 0.22 & 194 to 282 & No film formation \\
\hline & & 3.4 & 25 & 0.214 & -0.735 & 0.216 & -0.733 & 0.18 & 282 to 479 & No film formation \\
\hline \multirow{5}{*}{4} & \multirow{5}{*}{316} & 4.1 & 60 & $N / A^{[2]}$ & $\mathrm{N} / \mathrm{A}^{[2]}$ & $N / A^{l: T}$ & $\bar{N} / A^{|2|}$ & 0.43 & 0 to 137 & No film formation \\
\hline & & 4.2 & 20 & $\mathrm{~N} / \mathrm{A}^{[2]}$ & $\mathrm{N} / \mathrm{A}^{[2]}$ & N/A $A^{2 i}$ & $N / A^{[2]}$ & 0.14 & 137 to 497 & No film formation \\
\hline & & 4.3 & 15 & $\mathrm{~N} / \mathrm{A}^{[2]}$ & $N / A^{[2]}$ & $\mathrm{N} / \mathrm{A}^{[2]}$ & $\mathrm{N} / \mathrm{A}^{[2]}$ & 0.11 & 497 to 643 & No film formation \\
\hline & & 4.4 & 10 & $\mathrm{~N} / \mathrm{A}^{[\mathrm{l}]}$ & $\mathrm{N} / \mathrm{A}^{\mathrm{I}^{-2}}$ & $\mathrm{~N} / \mathrm{A}^{[2]}$ & $\mathrm{N} / \mathrm{A}^{[2]}$ & 0.07 & 643 to 815 & No film formation \\
\hline & & 4.5 & 5 & $\mathrm{~N} / \mathrm{A}^{12}$ & $N / A^{[2]}$ & $\mathrm{N} / \mathrm{A}^{[2]}$ & $\mathrm{N} / \mathrm{A}^{[2]}$ & 0.04 & 815 to 1054 & Film formation \\
\hline \multirow{2}{*}{5} & \multirow{2}{*}{316} & 5.1 & 40 & 0.200 & -0.749 & 0.203 & $-0 . \overline{746}$ & 0.29 & 0 to 169 & No film formation \\
\hline & & 5.2 & 20 & 0.216 & -0.733 & 0.218 & -0.731 & 0.14 & 169 to 239 & No film formation \\
\hline \multirow{5}{*}{6} & \multirow{5}{*}{316} & 6.1 & 20 & $\mathrm{~N} / \mathrm{A}$ & $N / A$ & N/A & $\mathrm{N} / \mathrm{A}$ & 0.14 & 0 to 148 & No tilm formation \\
\hline & & 6.2 & 15 & 0.223 & -0.726 & 0.225 & -0.724 & 0.11 & 148 to 215 & No film formation \\
\hline & & 6.3 & 10 & 0.231 & -0.718 & 0.234 & -0.715 & 0.07 & 215 to 316 & No film formation \\
\hline & & 6.4 & 5 & 0.246 & -0.703 & $\mathrm{~N} / \mathrm{A}^{[2]}$ & $N / A^{[?]}$ & 0.04 & 316 to 364 & Film formation \\
\hline & & 6.5 & 20 & 0.215 & -0.734 & $N / A^{[2]}$ & $\mathrm{N} / \mathrm{A}^{[2]}$ & 0.14 & 364 to 391 & 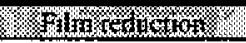 \\
\hline \multirow{4}{*}{7} & \multirow{4}{*}{316} & 7.1 & 20 & 0.216 & -0.733 & 0.218 & -0.731 & 0.14 & 0 to 22 & No film formation \\
\hline & & 7.2 & 10 & 0.231 & -0.718 & 0.234 & -0.715 & 0.07 & 22 to 114 & No film formation \\
\hline & & 7.3 & 5 & 0.245 & -0.704 & 0.249 & -0.700 & 0.04 & 114 to 451 & Film formation \\
\hline & & 7.4 & 10 & 0.231 & -0.718 & 0.236 & -0.713 & 0.07 & 451 10 555 & 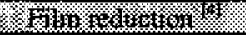 \\
\hline \multirow{3}{*}{8} & \multirow{3}{*}{316} & 8.1 & 40 & 0.203 & -0.746 & 0.207 & -0.742 & 0.29 & 0 to 119 & No film formation \\
\hline & & 8.2 & 5 & 0.246 & .0 .703 & 0.251 & -0.698 & 0.04 & 119 to 365 & Film formetion \\
\hline & & 8.3 & 15 & 0.222 & -0.727 & 0.227 & -0.722 & 0.11 & 365 to 600 & 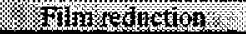 \\
\hline & & 9.1 & 15 & 0.222 & -0.727 & 0.228 & -0.721 & 0.11 & 0 to 141 & No film formation \\
\hline 9 & 316 & 9.2 & 5 & 0.247 & .0 .702 & 0.252 & -0.697 & 0.04 & 141 to 241 & Film formation \\
\hline & & 9.3 & 10 & 0.233 & -0.716 & 0.238 & -0.711 & 0.07 & 241 to 358 & 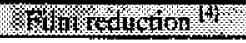 \\
\hline & & 10.1 & 25 & $\mathrm{~N} / \mathrm{A}^{[2]}$ & $N / A^{[2]}$ & $\mathrm{N} / \mathrm{A}^{[2]}$ & $N / A^{[2]}$ & 0.18 & 0 to 11 & No film formation \\
\hline & & 10.2 & 20 & $\mathrm{~N} / \mathrm{A}^{[2]}$ & $N / A^{(2)}$ & $N / A^{[2]}$ & $\mathrm{N} / \mathrm{A}^{[2]}$ & 0.14 & 11 to 13 & No film formation \\
\hline 10 & 316 & 10.3 & $\mathrm{~N}_{2}$ sparge & $\mathrm{N} / \mathrm{A}^{[2]}$ & $\mathrm{N} / \mathrm{A}^{[2]}$ & $\mathrm{N} / \mathrm{A}^{[?]}$ & $\mathrm{N} / \mathrm{A}^{[2]}$ & N/A & 13 to 17 & Ifilm formation \\
\hline & & 10.4 & 20 & $N / A^{[2]}$ & $\mathrm{N} / \mathrm{A}^{[2]}$ & $\mathrm{N} / \mathrm{A}^{[2]}$ & $\mathrm{N} / \mathrm{A}^{[\mathrm{I}]}$ & 0.14 & 17 to 21 & 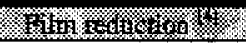 \\
\hline & & 10.5 & 30 & $N / A^{[2]}$ & $\mathrm{N} / \mathrm{A}^{[\%]}$ & $\mathrm{N} / \mathrm{A}^{[2]}$ & $\mathrm{N} / \mathrm{A}^{[2]}$ & 0.22 & 21 to 27 & Film reduction \\
\hline 11 & 338 & 11.1 & 40 & 0.222 & -0.768 & 0.224 & -0.766 & 0,20 & 0 to 162 & No film formation \\
\hline & & 12.1 & 40 & 0.222 & -0.768 & 0.223 & -0.767 & 0.20 & 0 to 67 & No film formation \\
\hline & & 12.2 & 19 & 0.238 & -0.752 & 0.238 & -0.752 & 0.10 & 67 to 114 & No film formation \\
\hline 12 & 338 & 12.3 & 15 & 0.246 & -0.744 & 0.247 & -0.743 & 0.08 & 114 to 234 & No film formation \\
\hline 12 & 398 & 12.4 & 10 & 0.255 & -0.735 & 0.256 & -0.734 & 0.05 & 234 to 283 & Film formation \\
\hline & & 12.5 & 15 & 0.245 & -0.745 & 0.249 & -0.741 & 0.08 & 283 to 453 & 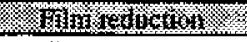 \\
\hline & & 12.6 & 19 & 0.238 & -0.752 & $N / A^{[2]}$ & $N / A^{[2]}$ & 0.10 & 453 to 479 & Film reduction \\
\hline & & I3.1 & 90 & 0.219 & -0.829 & 0.222 & -0.826 & 0.31 & 0 to 161 & No film fonnation \\
\hline & & 13.2 & 30 & $\mathrm{~N} / \mathrm{A}^{(2)}$ & $N / A^{[2]}$ & $N / A^{[2]}$ & $\mathrm{N} / \mathrm{A}^{[2]}$ & 0.10 & 161 to 209 & No film formation \\
\hline & & 13.3 & 20 & $\mathrm{~N} / \mathrm{A}^{\mathrm{PI}}$ & $\mathrm{N} / \mathrm{A}^{[3}$ & $N / A^{[2]}$ & $\mathrm{N} / \mathrm{A}^{123}$ & 0.07 & 209 to 235 & Film formation \\
\hline 13 & 360 & 13.4 & 30 & $N / A^{[2]}$ & $\mathrm{N}^{2} \mathrm{~A}^{[2]}$ & $\mathrm{N} / \mathrm{A}^{[2]}$ & $\mathrm{N} / \mathrm{A}^{\left[T^{2}\right.}$ & 0.10 & 235 to 353 & \& \& \\
\hline & & 13.5 & 35 & $\mathrm{~N} / \mathrm{A}^{\text {2) }}$ & ${\mathrm{N} / \mathrm{A}^{[2]}}^{2}$ & $\mathrm{~N}^{\mathrm{A}} \mathrm{A}^{[2]}$ & $\mathrm{N} / \mathrm{A}^{[2]}$ & 0.12 & 353 to 423 & Film reduction ${ }^{(4)}$ \\
\hline & & 13.6 & 40 & $N / A^{[2]}$ & $N / A^{[2]}$ & $\mathrm{N} / \mathrm{A}^{[2]}$ & $N / A^{[2]}$ & 0.14 & 423 to 495 & Film reduction ${ }^{[+]}$ \\
\hline & & 13.7 & 60 & $\mathrm{~N} / \mathrm{A}^{[2]}$ & $\mathrm{N} / \mathrm{A}^{[2]}$ & $\mathrm{N} / \mathrm{A}^{[2]}$ & $N / A^{\mid[\mid]}$ & 0.21 & 49510530 & Film reduction ${ }^{[A]}$ \\
\hline
\end{tabular}

(1) ECP data were converted from the $\mathrm{Fe} / \mathrm{Fe}, \mathrm{O} 4$ scale to the $\mathrm{SHE}$ scale by subtracting $0.916,0.949,0.990$ and 1.048 Volts at 288, 316, 338 and $360^{\circ} \mathrm{C}$. respectively. These values were calculated using the Nemst equation and thermodynamic data from Zienwiak ${ }^{\prime 2}$.

[2] Data not available $(\mathrm{N} / \mathrm{A})$ due to failure of the $\mathrm{Fe} / \mathrm{Fe}_{3} \mathrm{O}_{4}$ reference electrode, or because a steady-state potential was not reached.

[3] Calculated using Henry's Law coefficients of $1.06 \times 10^{-2}, 7.19 \times 10^{3}, 5.08 \times 10^{3}$ and $3.47 \times 10^{3}$ atm/(scc/kg) at $288,316,338$ and $360{ }^{\circ} \mathrm{C}$. 
[4) Film reduction definitely occurred, but the reduction was nor complete (te., the final resintonce war somewhar higher than prior fo film formation), at least in the time allorted for char phase of the tert

Data at $288^{\circ} \mathrm{C}$ are showa in Table 1. No film formation was observed down to $5 \mathrm{scc} / \mathrm{kg} \mathrm{H}$. Fulm formation was evident at 3 sec/kg $\mathrm{H}_{2}$, though the rate of increase in resistance was slower than that shown in Figures 2 to 6 . Partial reduction occurred upon switching back to $5 \mathrm{scc} / \mathrm{kg} \mathrm{H}_{2}$ and complete reduction was observed at 10 scc/kg $\mathrm{H}_{2}$. In the next test, a film was formed at a $\mathrm{N}_{2}$ sparge condition and full reduction was observed at $5 \mathrm{scc} / \mathrm{kg} \mathrm{H}_{2}$. Thus, the Ni/NiO transition at $288^{\circ} \mathrm{C}$ resides at $-45 c c / \mathrm{kg} \mathrm{H}_{2}$. Data at $360^{\circ} \mathrm{C}$ are shown in Table $\mathrm{I}_{\text {. Film formation was }}$ evident at 20 sce/kg Hz. Reduction occurred at 30 sce/kg H , though the reduction was not complete. The $\mathrm{Ni} / \mathrm{NiO}$ transition is judged to reside at $25 \mathrm{sco} / \mathrm{kg} \mathrm{H}$ at $360^{\circ} \mathrm{C}$. However, note that since this test has not been replicated, the $\mathrm{Ni} / \mathrm{NiO}$ uransition at $360^{\circ} \mathrm{C}$ is less definite than for the other temperatures at which more testing has been conducted.

\section{Verification using corrosion coupoins and $\mathrm{x}$-ray diffraction}

The results obtained from the CER were spot-checked using corrosion coupon exposure. A nickel coupon was exposed to 20 sce/kg $\mathrm{H}_{2}$ at $338^{\circ} \mathrm{C}$ for 10 days. As shown in Figure 7 , the coupon was essentially film-free after exposure to this autoclave environment, verifying that this condition does indeed reside on the $\mathrm{Ni}$ side of the $\mathrm{Ni} / \mathrm{NiO}$ transition. A second nickel coupon was exposed in a different autoclave to the same nominal conditions (20 see/kg $\mathrm{H}_{2}$ at $338^{\circ} \mathrm{C}$ ). for 10.7 days, for the purposes of replication. Again, the coupon was essentially film-free after exposure. It is noled that the corrosion coupon data and the CER data at this condition are complementary. Specifically. the coupon data verified the absence of oxide after autoclave exposure to 20 sce $/ \mathrm{kg} \mathrm{H}_{2}$ at $338^{\circ} \mathrm{C}$ for -10 days, but these data alone do not resolve the question of whether an oxide might form during a longer exposure time. However, the faet that the CER showed reduction of a growing axide at 15 sec/kg $\mathrm{H}_{2}$ provides. additional strong evidence that 20 sce/ $\mathrm{kg} \mathrm{H}_{2}$ is indeed located in the Ni regime at $338^{\circ} \mathrm{C}$. An Alloy 600 coupon was placed in the

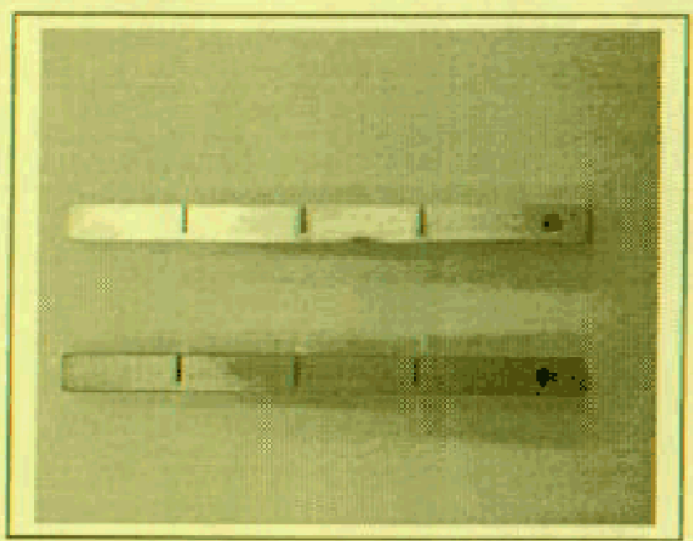

Figure 7. Ni coupon (upper specimen) and Alloy 600 coupon (lower specimen) exposed to $338^{\circ} \mathrm{C}$ at $20 \mathrm{scc} / \mathrm{kg} \mathrm{H}$ for 10 days. autoclave for the test conducted at 20 scolkg $\mathrm{H}_{2}$ and $338^{\circ} \mathrm{C}$ for 10.7 days. This coupon, as shown in Figure 7 . clearly exhibited film formation during the exposure. This data point proves that the autoclave exposure time $(-10$ days) is sufficiently long to cause film formation, at least on a $\mathrm{Ni}-\mathrm{Cr}$-Fe alloy (i.t., Alloy 600). Note, though, that the film on Alloy 600 is a spinel structure oxide (i.e., $\mathrm{Ni}_{2} \mathrm{Fe}_{\mathrm{I}_{1}} \mathrm{Cr}_{3} \mathrm{Fe}_{2, y} \mathrm{O}_{4}$ ) as opposed to nickel oxide.

Another nickel coupon was exposed to $12.5 \mathrm{scc} / \mathrm{kg} \mathrm{H} \mathrm{H}_{2}$ at $338^{\circ} \mathrm{C}$ for 63 days. As shown in Figure 8, this eoupon was covered with oxide, though it is noted that visually the oxide appeared to be lighter in color (and thus, likely thinner) than oxides typically observed afier autoclave exposure. Thus, the $12.5 \mathrm{scc} / \mathrm{kg} \mathrm{H}$ condition at $338^{\circ} \mathrm{C}$ is judged to reside just slightly into the $\mathrm{NiO}$ regime, and the $\mathrm{Ni} / \mathrm{NiO}$ transition at $338^{\circ} \mathrm{C}$ is estimated as $13.75 \pm 1.25 \mathrm{scc} / \mathrm{kg} \mathrm{H}$. Note that no resistance versus time data are available for the $12.5 \mathrm{scc} / \mathrm{kg} \mathrm{H}$ condition at $338^{\circ} \mathrm{C}$; the data in

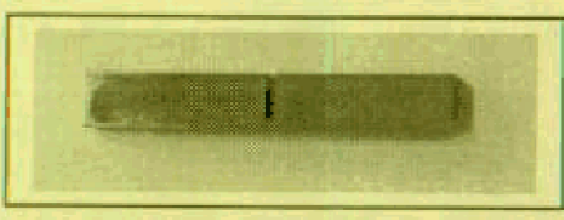

Figure 8. Ni coupon exposied to $338^{\circ} \mathrm{C}$ at $12.5 \operatorname{scohg} \mathrm{H}_{2}$ for 63 days.

Figure 6 imply that 10 see/ $\mathrm{kg} \mathrm{H}$ is in the $\mathrm{NiO}$ regime and 15 sec/kg $\mathrm{H}_{2}$ is in the $\mathrm{Ni}$ regime at $338^{\circ} \mathrm{C}$ but provide no information as to the expectation for the $12.5 \mathrm{sce} / \mathrm{kg} \mathrm{H} \mathrm{H}_{2}$ condition. The oxide observed on the coupon exposed to $12.5 \mathrm{scc} / \mathrm{kg} \mathrm{H} \mathrm{H}_{2}$ at $338^{\circ} \mathrm{C}$ was examined via x-ray diffraction and was found to consist of cubic nickel oxide (NiO).

Subsequently, one piece of the $\mathrm{Ni}_{\mathrm{i}}$ specimen referred to above (exposed to $12.5 \mathrm{scc} / \mathrm{kg} \mathrm{H}$ at $338^{\circ} \mathrm{C}$ for 63 days) was re-exposed at 20 sco/kg H$~_{2}$ at $338^{\circ} \mathrm{C}$ for 10.7 days. As shown in Figure 8 , a partial reduction of the oxide occurred, with the oxide becoming 'patchy' after the second exposure. Areas of

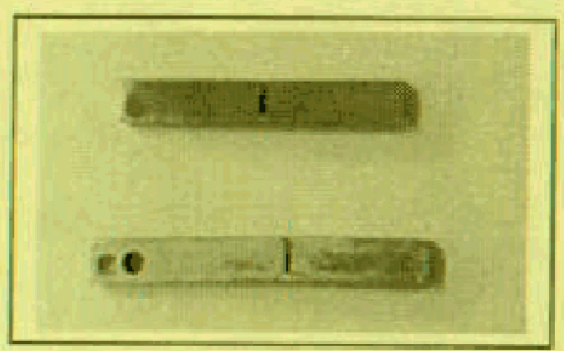

Figure 9. Ni coupons. Upper specimen is same as shown in Figure 8. Lower specimen is the other half of the upper specimen, which was re' exposed to $338^{\circ} \mathrm{C}$ at 20 $s c \mathrm{~kg} \mathrm{H}_{2}$ for $\mathrm{IO}$ days. 
essentially bare metal were noted after the second exposure (Figure 9). This result suggests that the second exposure did not simply provide a uniform partial reduction (i.e., uniform thinning) of the film; rather, it is expected that continued exposure would have fully reduced the oxide. This data point supports the notion that the $20 \mathrm{scc} / \mathrm{kg} \mathrm{H}$ condition at $338^{\circ} \mathrm{C}$ resides in the Ni regime. Additionally, the reduction of this oxide confirms that there is no bias in the results due to the fact that the exposure time for the coupon tested at $12.5 \mathrm{scc} / \mathrm{kg} \mathrm{H} \mathrm{H}_{2}$ (i.e., 63 days) was greater than the exposure times for the two separate coupons tested at $20 \mathrm{scc} / \mathrm{kg} \mathrm{H}_{2}$ (i.e., 10 and 10.7 days).

Summary of $\mathrm{Ni} / \mathrm{NiO}$ data and comparison with theoretical predictions

Figure 10 summarizes CER data at 288,316 , 338 and $360^{\circ} \mathrm{C}$. The experimentally measured $\mathrm{Ni} / \mathrm{NiO}$ transition was evaluated as the midpoint between the least reducing condition in the $\mathrm{Ni}$ regime and the least oxidizing condition in the NiO regime. Data from Ehrnsten and Saario ${ }^{10}$ are also shown on the plot. These data are broadly consistent with the $\mathrm{Ni} / \mathrm{NiO}$ transition determined experimentally in this work, though it is noted that the prior work was not conducted at $\mathrm{H}_{2}$ levels near the apparent $\mathrm{Ni} / \mathrm{NiO}$ transition. The prior investigators ${ }^{10}$ observed a resistance characteristic of the film-covered condition in a nitrogen sparge test at $320^{\circ} \mathrm{C}$ and also observed resistance values characteristic of the film-free condition at 25 and $30 \mathrm{scc} / \mathrm{kg} \mathrm{H}_{2}$ at both 288 and $320^{\circ} \mathrm{C}$.

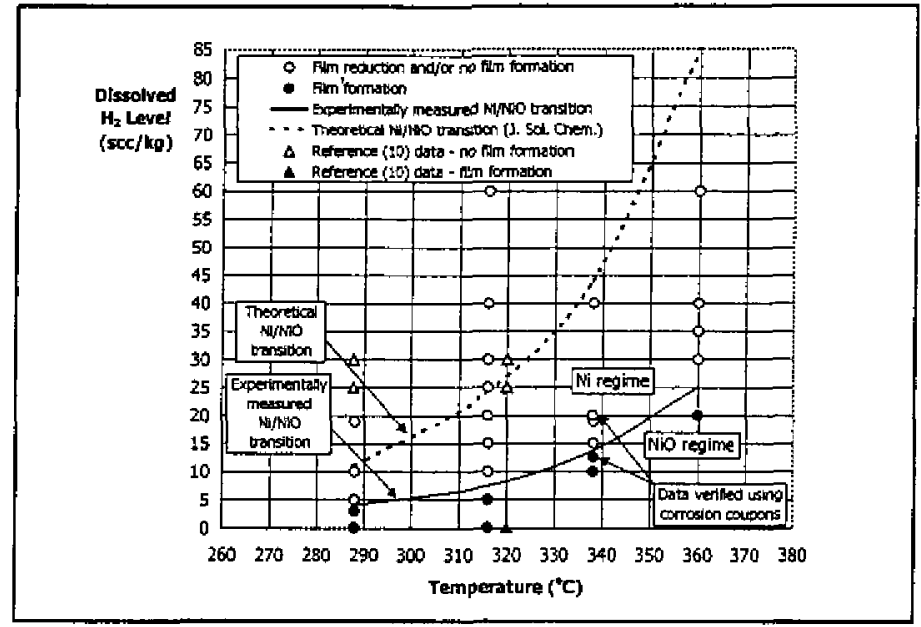

Figure 10. Summary plot of CER data, on an scc/kg $\mathrm{H}_{2}$ basis.

A substantial deviation is evident between the experimentally measured $\mathrm{Ni} / \mathrm{NiO}$ transition and the theoretical $\mathrm{Ni} / \mathrm{NiO}$ transition calculated by some of the present authors ${ }^{3}$ using thermodynamic data from the Journal of Solution Chemistry ${ }^{12,14}$. The coupon data obtained at $20 \mathrm{scc} / \mathrm{kg} \mathrm{H}$ at $338^{\circ} \mathrm{C}$ show that the CER-measured $\mathrm{Ni} / \mathrm{NiO}$ line is a more accurate representation of this transition than the theoretically calculated line (note that in a separate paper ${ }^{15}$, the measured data are used to derive more accurate thermodynamic data (i.e., $\Delta \mathrm{H}, \Delta \mathrm{S})$ ) and an equation for the measured $\mathrm{Ni} / \mathrm{NiO}$ transition is provided). A lesser deviation is evident between the experimentally measured $\mathrm{Ni} / \mathrm{NiO}$ transition and the theoretical $\mathrm{Ni} / \mathrm{NiO}$ transition cited by Cassagne et al. ${ }^{1}$ As shown in Figure 10, the experimentally

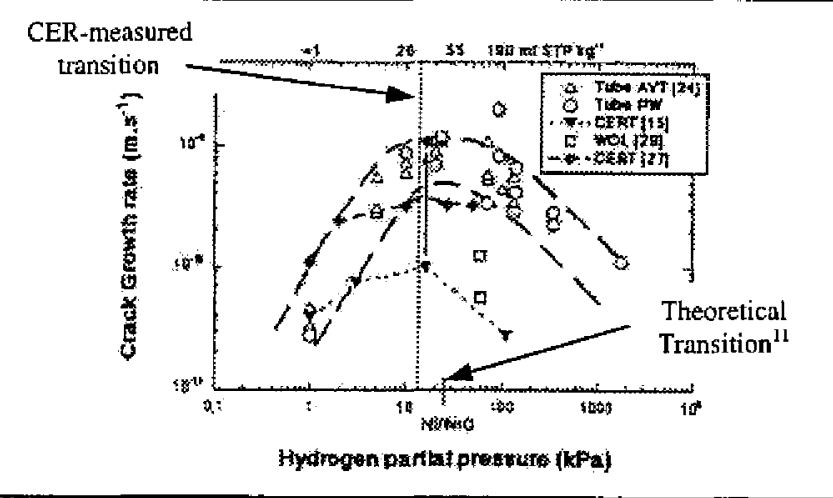

Figure II. Alloy $600 \mathrm{CGR}$ data at $360^{\circ} \mathrm{C} .^{\text {II }}$ Dashed line shows measured NiNiO transition.

measured $\mathrm{Ni} / \mathrm{NiO}$ transition at $360^{\circ} \mathrm{C}$ is at $\sim 25 \mathrm{scc} / \mathrm{kg} \mathrm{H}$. This point is somewhat lower than the calculated $\mathrm{Ni} / \mathrm{NiO}$ transition shown as a short vertical bar (and labeled as $\mathrm{Ni} / \mathrm{NiO}$ ) on the lower $\mathrm{x}$-axis of Figure 11 (note that the units of $\mathrm{ml} \mathrm{STP} \mathrm{kg}{ }^{-1} \mathrm{H}_{2}$ shown on the upper $\mathrm{x}$-axis of Figure 11 are equivalent to $\mathrm{scc} / \mathrm{kg} \mathrm{H}_{2}$ ). It is noted, however, that only one test has been conducted at $360^{\circ} \mathrm{C}$ in the present study, so the confidence in the measured $\mathrm{Ni} / \mathrm{NiO}$ transition at that temperature is not as great as at 316 and $338^{\circ} \mathrm{C}$ for which more extensive testing has been performed.

The cause of the discrepancy shown in Figure 10 between the theoretical $\mathrm{Ni} / \mathrm{NiO}$ transition and the measured transition has not yet been identified. Possible sources of the discrepancy are: (i) errors in the free energy of formation of $\mathrm{NiO}$ (or, less likely, $\mathrm{H}_{2} \mathrm{O}$ ) at 288 to $360^{\circ} \mathrm{C}$, (ii) the free energy of formation of a surface oxide (e.g., an $\mathrm{NiO}$ film) is different from that of a bulk oxide, (iii) enrors in the elevated temperature Henry's law coefficient which converts theoretically calculated hydrogen fugacities to units of concentration (i.e., $\mathrm{scc} / \mathrm{kg}$ ), or (iv) changes in the density/compressibility of water are not adequately accounted for. Further study is needed to resolve this issue. 
Implications for the effects of aqueous hydrogen level on PWSCC

Figure 12 shows SCCGR data ${ }^{3.5 .15}$ for Alloy X-750 in the $\mathrm{HTH}$ heat treatment at $360^{\circ} \mathrm{C}$. It is evident that the maximum in PWSCC susceptibility is in much closer agreement with the experimentally measured $\mathrm{Ni} / \mathrm{NiO}$ transition than with the theoretical $\mathrm{Ni} / \mathrm{NiO}$ transition reported previously ${ }^{3}$. The agreement is also very good for Alloy 600 (at $338^{\circ} \mathrm{C}$ ), as shown in Reference 15. The agreement is reasonable though not as close for Alloy X-750 in the $\mathrm{AH}$ heat treatment (at $338^{\circ} \mathrm{C}$ ).$^{15}$ It is speculated that this result may be due to the fact that large portions of the oxide in the cracks in Alloy $\mathrm{X}-750 \mathrm{AH}$ are (Ni,Nb,Ti)O, in contrast to the cubic $\mathrm{NiO}$ structure (i.e., $(\mathrm{Ni}, \mathrm{Cr}, \mathrm{Fe}) \mathrm{O}$ ) often found as the crack tip oxide in Alloy 600 and Alloy X-750 HTH. ${ }^{6}$ Figure 11 also shows that for a different set of data (reported by Cassagne et al. ${ }^{1}$ ), the experimentally measured $\mathrm{Ni} / \mathrm{NiO}$ transition is in close agreement with the peak in SCC susceptibility for Alloy 600, though it is acknowledged that the peak is quite broad in this figure.

This work has two major implications for understanding and predicting the effect of aqueous $\mathrm{H}_{2}$ level on PWSCC. First, the fact that the maximum in PWSCC susceptibility is in close agreement with the experimentally measured $\mathrm{Ni} / \mathrm{NiO}$ transition underscores a point made previously by other investigators ${ }^{16}$, namely that a corrosion process is likely involved in the mechanism of PWSCC, with the oxide perhaps being metastable in the vicinity of the $\mathrm{Ni} / \mathrm{NiO}$ transition. Secondly, this work provides insight related to extrapolating the effects of aqueous $\mathrm{H}_{2}$ to lower temperatures. In other words, extensive accelerated SCC testing has been conducted at 338, 360 and $399^{\circ} \mathrm{C}^{1-5,15}$ to determine the effect of

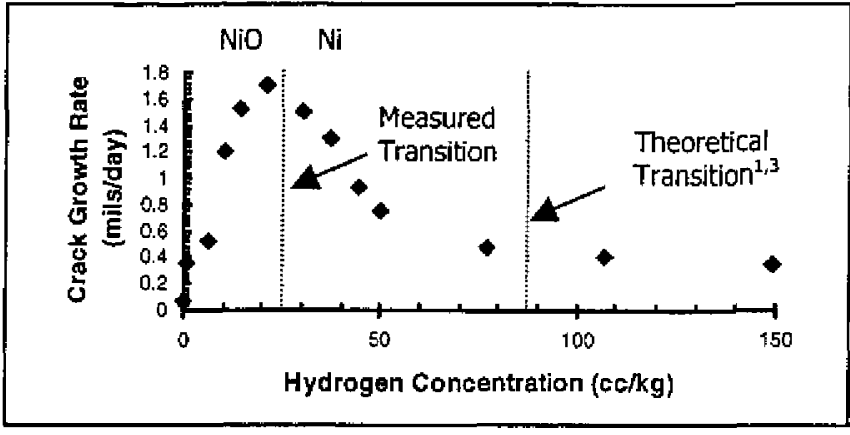

Figure 12. SCCGR data for Alloy X-750 HTH at $360^{\circ} \mathrm{C}^{15}$ aqueous $\mathrm{H}_{2}$, but such tests are time-consuming to perform at lower temperatures. The present work provides the experimentally measured $\mathrm{Ni} / \mathrm{NiO}$ transition at lower temperatures (down to $288^{\circ} \mathrm{C}$, with the possibility of extrapolating to lower temperatures if needed). The $\mathrm{Ni} / \mathrm{NiO}$ transition provides a reasonable basis for estimating the aqueous $\mathrm{H}_{2}$ level at which the maximum in SCC susceptibility is likely to be observed, at a variety of temperatures.

Limited data acquired at $288^{\circ} \mathrm{C}$ are consistent with the notion that SCCGR of nickel-based alloys is heightened in the vicinity of the $\mathrm{Ni} / \mathrm{NiO}$ transition at lower temperatures. The present SCCGR testing was conducted at 10 and 50 scc/kg $\mathrm{H}_{2}$ on EN82H weld metal. The specimens were fabricated from a weld cradle made from a single heat of weld wire using a cold wire automatic gas tungsten arc welding process. The shield gas was $100 \%$ argon, and the specimens were tested in the as-welded condition. Specimens were 1T compact tension specimens, side grooved to a net thickness of 0.798 " and air fatigue precracked to an initial crack depth-to-specimen width ratio (a/W) of -0.5 . Testing was conducted in the T-S orientation (i.e., with the load applied perpendicular to the weld pass direction and with the crack growing from the root to the crown of the weld). Constant load was applied using an electric actuator, with an initial stress intensity factor $\left(\mathrm{K}_{\mathrm{l}}\right)$ of $35 \mathrm{ksivin}$. The $\mathrm{pH}$ of the water was similar to that described previously for the CER testing. The test conditions and SCCGR results are summarized in Table 2.

Table 2. SCCGR testing of EN82H weld metal at $288^{\circ} \mathrm{C}$

\begin{tabular}{|c|c|c|c|c|}
\hline $\begin{array}{c}\text { Specimen } \\
\text { Identification }\end{array}$ & $\begin{array}{c}\text { Aqueous } \mathrm{H}_{2} \text { level } \\
\left(\mathrm{scc} / \mathrm{kg} \mathrm{H} \mathbf{H}_{2}\right)\end{array}$ & $\begin{array}{c}\Delta \mathrm{a}_{S C C_{\text {,max }}} \\
(\mu \mathrm{m})\end{array}$ & $\begin{array}{c}\text { Exposure time } \\
\text { (days) }\end{array}$ & $\begin{array}{l}\text { Estimated lower bound } \\
\text { SCCGR }_{\max }(\mu \mathrm{m} / \mathrm{hour})\end{array}$ \\
\hline ES4-05 & 50 & 180 & 172.7 & 0.043 \\
\hline ES4-06 & 50 & 240 & 84.9 & 0.12 \\
\hline ES4-03 & 10 & 1350 & 77.7 & 0.720 \\
\hline
\end{tabular}

The crack front was highly non-uniform, as expected for weld metal ${ }^{17}$, with $\mathrm{SCC}$ occurring in several isolated pockets rather than continuously across the crack front. As a result, only a maximum crack extension $\left(\Delta \mathrm{a}_{s c c, \max }\right)$, as opposed to an average crack extension, is reported. Additionally, the crack monitoring instrumentation (electric 
potential drop monitoring, EPM) was ineffective at detecting the onset (i.e., incubation) of SCC growth, since uniform SCC across the front of the fatigue precrack is needed for reliable in-situ monitoring. Thus, an estimated lower-bound $S_{C C G R}$ max is reported, assuming an incubation time of zero. As shown in Table 2, significantly more crack extension occurred at $10 \mathrm{scc} / \mathrm{kg} \mathrm{H}_{2}$ as compared to $50 \mathrm{scc} / \mathrm{kg} \mathrm{H}_{2}$. Figure 13 demonstrates that these data points, while limited in number, are consistent with the view that $S C C$ susceptibility increases as one approaches the $\mathrm{Ni} / \mathrm{NiO}$ transition (which is located at $-4 \mathrm{scc} / \mathrm{kg} \mathrm{H}_{2}$ at $288^{\circ} \mathrm{C}$ according to the CER data). Thus, the SCCGR data suggest that the result previously demonstrated at 338,360 and $399^{\circ} \mathrm{C}$ (i.e., increased PWSCC susceptibility in the vicinity of the $\mathrm{Ni} / \mathrm{NiO}$ transition) is also obtained

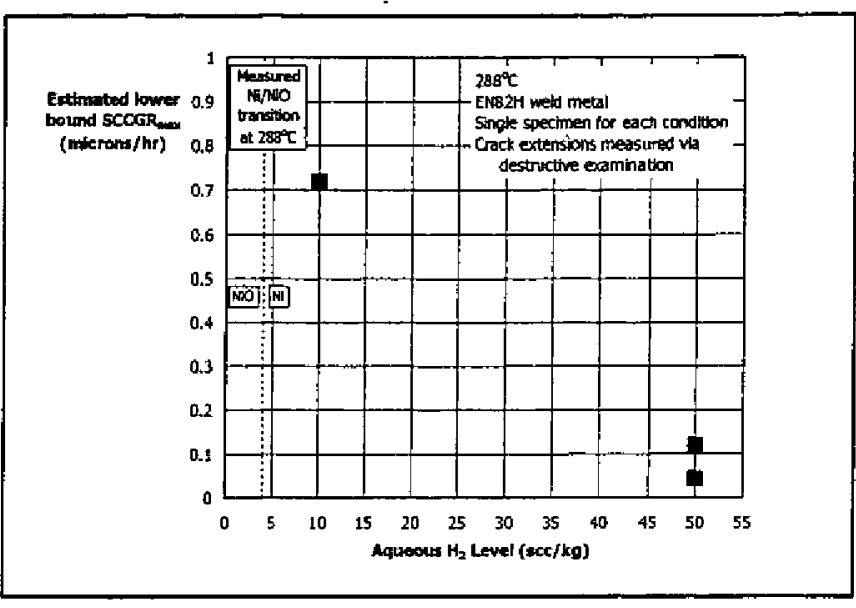

Figure 13. SCCGR data for EN82H at $288^{\circ} \mathrm{C}$. at lower temperatures. Note that these data were collected using a single specimen at each $\mathrm{H}_{2}$ level, and that the SCC extent was determined via destructive examination. EPM was used solely in an attempt to detect the onset (i.e., incubation) of cracking, not to measure crack growth rates.

As illustrated in Figures 11,12 and 13, operation in the $\mathrm{Ni}$ stability regime does not eliminate cracking. It is important to note that this observation does not preclude a role of corrosion in the $\mathrm{SCC}$ process, since $\mathrm{Ni}-\mathrm{Cr}-\mathrm{Fe}$ alloys still exhibit significant oxidation in the $\mathrm{Ni}$ regime. In fact, not only is the corrosion of $\mathrm{Fe}$ and $\mathrm{Cr}$ thermodynamically favored in the $\mathrm{Ni}$ stability regime, but the corrosion of $\mathrm{Ni}$ to form spinel oxides $\left(\mathrm{Ni}_{\mathrm{x}} \mathrm{Fe}_{1-\mathrm{x}} \mathrm{Cr}_{\mathrm{y}} \mathrm{Fe}_{2}\right.$ ${ }_{y} \mathrm{O}_{4}$ ) can still occur on the $\mathrm{Ni}$ side of the $\mathrm{Ni} / \mathrm{NiO}$ equilibrium. The film-covered Alloy 600 coupon shown in Figure 7 provides an example of corrosion of a $\mathrm{Ni}-\mathrm{Cr}-\mathrm{Fe}$ alloy in the $\mathrm{Ni}$ regime.

\section{Relevance to Ni-Cr-Fe alloys}

Although no CER testing has yet been performed on Ni-Cr-Fe alloys such as Alloy 600 , Alloy X-750, or Alloy 718 , it is important to recognize that CER tests using pure Ni are directly applicable to PWSCC of Ni-Cr-Fe alloys. As mentioned previously, the crack tip oxide for $\mathrm{Ni}-\mathrm{Cr}-\mathrm{Fe}$ alloys is often found to exhibit a $\mathrm{NiO}$ structure ${ }^{6}$, suggesting that $\mathrm{NiO}$ may be an SCC-controlling oxide. Also, the fact that the experimentally measured $\mathrm{Ni} / \mathrm{NiO}$ transition is in good agreement with the maximum in PWSCC susceptibility for $\mathrm{Ni}-\mathrm{Cr}-\mathrm{Fe}$ alloys provides persuasive evidence that the data obtained on pure $\mathrm{Ni}$ are important to understanding the SCC performance of the $\mathrm{Ni}-\mathrm{Cr}-\mathrm{Fe}$ alloys. Note also that the presence of a spinel oxide may impede the ability to measure the $\mathrm{Ni} / \mathrm{NiO}$ transition using $\mathrm{Ni}-\mathrm{Cr}$ - $\mathrm{Fe}$ alloys.

$\mathrm{Ni} / \mathrm{NiO}$ transition as a function of hydrogen fugacity

The CER facility is presently being equipped with a silver/palladium (Ag/Pd) cell, such that the $\mathrm{Ni} / \mathrm{NiO}$ transition will also be able to be reported on a hydrogen fugacity basis. Figure 14 provides an estimate of the transition on a hydrogen fugacity basis, using Henry's law to calculate hydrogen fugacity values from the known aqueous $\mathrm{H}_{2}$ level and temperature for each condition. The Henry's law coefficients used in this calculation ${ }^{12}$ are $1.06 \times 10^{-2}, 7.19 \times$ $10^{-3}, 5.08 \times 10^{-3}$ and $3.47 \times 10^{-3} \mathrm{~atm} /\left(\mathrm{scc} / \mathrm{kg} \mathrm{H}_{2}\right)$ at $288,316,338$ and $360^{\circ} \mathrm{C}$, respectively.

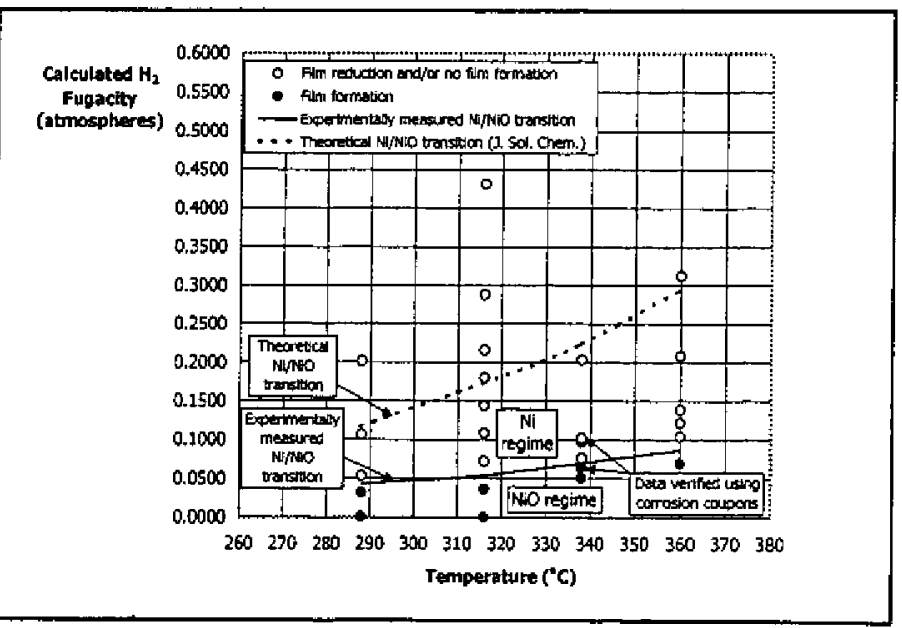

Figure 14. Summary plot on a fugacity basis. 
$\mathrm{Ni} / \mathrm{NiO}$ transition as a function of electrochemical potential

The iron/iron oxide $\left(\mathrm{Fe} / \mathrm{Fe}_{3} \mathrm{O}_{4}\right)$ electrode was used to measure $\mathrm{E}_{\text {corr }}$ values for $\mathrm{Ni}$, and Figure 15 shows the transition corrosion potentials as a function of temperature. It is noted that changing the temperature affects the potential of the $\mathrm{Fe} / \mathrm{Fe}_{3} \mathrm{O}_{4}$ electrode in addition to changing the $\mathrm{Ni} / \mathrm{NiO}$ transition.

The potentials are plotted on the standard hydrogen electrode (SHE) scale in Figure 16. The conversions from the $\mathrm{Fe} / \mathrm{Fe}_{3} \mathrm{O}_{4}$ scale to the SHE scale were conducted by subtracting $0.916,0.949,0.990$, and 1.048 Volts (V) at 288,316 , 338 and $360^{\circ} \mathrm{C}$, respectively. These values were calculated using the Nernst equation and thermodynamic data from Ziemniak $^{12}$.

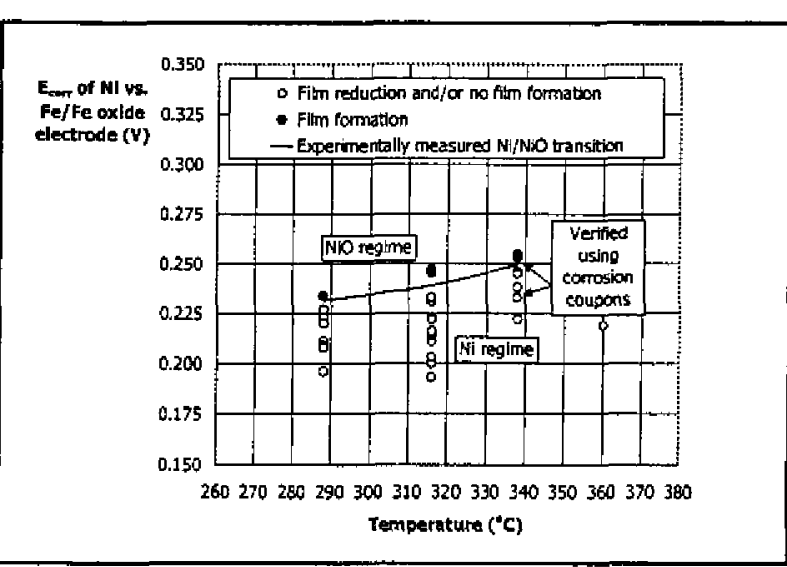

Figure 15. Summary plot on an ECP basis.

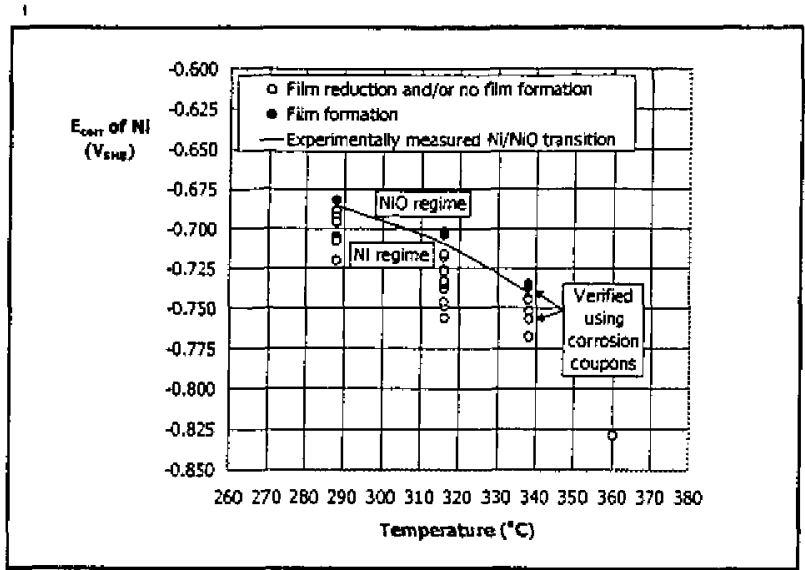

Figure 16. Summary plot on an ECP 1s. SHE basis.

\section{Conclusions}

1. The CER-measured transition $\mathrm{H}_{2}$ level for the $\mathrm{Ni} / \mathrm{NiO}$ equilibrium at 288 to $360^{\circ} \mathrm{C}$ was found to be lower than previously calculated by some of the present authors using thermodynamic data from the Journal of Solution Chemistry.

2. The CER data are consistent with corrosion coupon exposures at selected conditions.

3. The measured position of the $\mathrm{Ni} / \mathrm{NiO}$ transition is in good agreement with the maximum in PWSCC susceptibility for Alloy 600 at 338 and $360^{\circ} \mathrm{C}$ and for Alloy X-750 in the HTH heat treatment at $360^{\circ} \mathrm{C}$. The agreement is reasonable but not as close for Alloy X-750 in the $\mathrm{AH}$ heat treatment at $338^{\circ} \mathrm{C}$.

4. The measured $\mathrm{Ni} / \mathrm{NiO}$ transition provides a basis for estimating the aqueous $\mathrm{H}_{2}$ level at which the maximum in SCC susceptibility is likely to be observed at lower temperatures for which SCC tests are time-consuming to perform. The limited PWSCC data presented are consistent with the idea that SCC susceptibility is maximized in the vicinity of the $\mathrm{Ni} / \mathrm{NiO}$ transition at $288^{\circ} \mathrm{C}$.

\section{Acknowledgements}

Thanks to Maureen Schurman for providing the EN82H SCCGR data. Paul Sander performed the x-ray diffraction analysis. The CER equipment was procured from Cormet (Finland). Thanks to Nathan Lewis for technical review.

\section{References}

(1) T Cassagne, B Fleury, F Vaillant, O de Bouvier, P Combrade, Proceedings of the Eighth International Symposium on Environmental Degradation of Materials in Nuclear Power Systems, p. 307, 1997.

(2) G Economy, RJ Jacko and FW Pement, Corrosion, 43, No. 12, p. 727, 1987.

(3) DS Morton, SA Attanasio, JS Fish and MK Schurman, CORROSION/99 Paper No. 447, April 1999.

(4) JM Boursier, O de Bouvier, JM Gras, D Noel, R Rios and F Vaillant, Proceedings of the Conference on Corrosion Deformation Interactions, p. 117, Les editions de Physique, Paris, France (1992). 
(5) DS Morton, SA Attanasio, GA Young, PL Andresen, TM Angeliu, CORROSION/01, Paper No. 117, 2001.

(6) JS Fish, N Lewis, W Yang, DJ Perry and CD Thompson, Proceedings of the Eighth International Symposium on Environmental Degradation of Materials in Nuclear Power Systems, p. 266, 1997.

(7) N Lewis, SA Attanasio, DS Morton and GA Young, "Chemistry and Electrochemistry of Corrosion and Stress Corrosion Cracking: A Symposium Honoring RW Staehle", TMS, February 2001.

(8) RB Rebak and Z. Szklarska-Smialowska, Corrosion, Vol. 47, No. 10, p. 754, 1991.

(9) T Saario and V Marichev, EPRI IGA/SCC Workshop, San Antonio, Texas, December 1992.

(10) U Ehrnsten and T Saario, Fourth EPRI Workshop on PWSCC, Daytona Beach, Florida, 1997.

(11) T Saario, Ph.D. Thesis, Helsinki University of Technology, October 1995.

(12) SE Ziemniak, J. Sol. Chem., Vol. 21, No. 8, 1992.

(13) LW Niedrach, J. Electrochem. Soc., Vol. 129, No. 7, p. 1445, July 1982.

(14) LO Gilpatrick and HH Stone, Oak Ridge National Lab Reports ORNL-3127 (1961) and ORNL -3262 (1962).

(15) DS Morton, SA Attanasio and GA Young, Proceedings of the Tenth International Symposium on the Environmental Degradation of Materials in Nuclear Power Systems, 2001.

(16) PM Scott, Proceedings of the Ninth International Symposium on Environmental Degradation of Materials in Nuclear Power Systems, p. 3, August 1999.

(17) WH Bamford, JP Foster and RS Pathania, Proceedings of the Ninth International Symposium on Environmental Degradation of Materials in Nuclear Power Systems, p. 279, August 1999. 